\title{
Quantitative distribution of immunoglobulin- producing cells in gastric mucosa: relation to chronic gastritis and glandular atrophy
}

\author{
K VALNES, P BRANDTZAEG, K ELGJO, AND R STAVE \\ From the Laboratory for Immunohistochemistry and Immunopathology, Institute of Pathology, The National \\ Hospital, and Department of Internal Medicine, Ullevål Hospital, Oslo, Norway
}

SUMMARY Immunoglobulin (Ig)-producing immunocytes were quantified by paired immunofluorescence staining in specimens of gastric antral $(n=52)$ and body $(n=117)$ mucosa obtained from 45 patients with various gastrointestinal disorders. Enumerations were carried out in a $500 \mu \mathrm{m}$ wide zone from the muscularis mucosae to the lumen ('tissue unit'). The specimens were divided into three categories according to the degree of inflammation, and each specimen received a grade for atrophy (0-2). The total number of IgA-, IgM- and IgG-producing cells per tissue unit increased strikingly with increasing degree of inflammation, both in antral and body mucosa. IgA immunocytes predominated (61-91\%) in all specimens, but the IgG isotype showed the largest relative increase (four to 17-fold), particularly in the basal part of the mucosa. In this layer of the gastric body the proportion of IgG cells was also significantly raised in association with atrophy, irrespective of degree of inflammation. Locally produced IgG may be of protective significance in terms of internal (or 'second line') defence but may at the same time maintain immunopathological mechanisms contributing to the chronicity of gastritis.

Histopathological characterisation of chronic gastritis is usually based on the density of inflammatory cells and the degree of mucosal atrophy. The immunoglobulin (Ig)-producing plasma cells and their immediate precursors (B-cell blasts) are important local effector cells, both in terms of mucosal protection and immunopathology. This protection involves primarily specific humoral defence by the secretory $\operatorname{IgA}$ (and IgM) system ${ }^{12}$; after being produced by local immunocytes, dimeric $\operatorname{IgA}$ and pentameric IgM are selectively transported by means of secretory component as a receptor ${ }^{3}$ through restricted parts of the gastric epithelium. ${ }^{4}$

It has recently been shown that epithelial expression of secretory component and uptake of $\operatorname{IgA}$ are enhanced in gastritis. ${ }^{5}$ The associated cellular IgA response in the lamina propria, however, related to the degree of inflammation has not been previously quantified. Also, the relative participation of immunocytes of other isotypes (IgM, IgG, IgD, and IgE) in gastritis has not been conclusively

Address for correspondence: Kolbjørn Valnes, Institute of Pathology, Rikshospitalet, 0027 Oslo 1. Norway.

Received for publication 28 August 1985. established, whereas such aspects of local immunity have been extensively defined in normal and diseased intestinal mucosa. ${ }^{6-10}$ In the present study, therefore, immunohistochemical quantitation of Igproducing cells was related to chronic gastritis and glandular atrophy in human stomach múcosa.

\section{Methods}

SPECIMENS AND TISSUE PREPARATION

Specimens of gastric antral $(n=52)$ and body $(n=117)$ mucosa were obtained from 21 women and 24 men with a median age of 43 years (range, 15-72 years). The material was collected surgically from 21 individuals of the following categories: patients subjected to Billroth II resection for duodenal or gastric ulcer $(n=15)$; patients operated for duodenal or gastric neoplasia $(n=2)$; and kidney donors $(n=4)$. In addition, biopsy specimens obtained through a Crosby's capsule from patients with coeliac disease $(n=11)$ or 'non-ulcer dyspepsia' $(n=13)$ were included.

The tissue samples were excised from macroscopically normal mucosa or, when taken with the Crosby's capsule, from stomachs without endo- 
scopically or radiographically overt lesions. After prewashing in $0.01 \mathrm{M}$ phosphate buffer, $\mathrm{pH} 7.6$, containing $0.15 \mathrm{M} \mathrm{NaCl}$ (PBS), the specimens were fixed in cold $96 \%$ ethanol and embedded in paraffin. ${ }^{11}$

\section{IMMUNOHISTOCHEMICAL REAGENTS AND}

STAINING PROCEDURES

Antisera to the five human Ig isotypes were raised in rabbits and rendered monospecific by appropriate solid phase absorptions. ${ }^{12} 13$ The IgG fractions of the antisera were labelled with fluorescein isothiocyanate or tetramethylrhodamine isothiocyanate $^{12}$; the characteristics of the purified conjugates are shown in Table 1. Performance tests on negative and positive substrates, and absorption controls with appropriate soluble antigens, confirmed the specificity of immunohistochemical staining. ${ }^{13} 14$

Serial sections were cut at $6 \mu \mathrm{m}$ perpendicular to the mucosal surface, dewaxed, and stained either with a haematoxylin, azopholoxine, and saffron trichrome method ${ }^{15}$ or by direct paired immunofluorescence with various conjugate combinations as shown in Table 1. The major Ig classes (IgA, IgM, and $\operatorname{IgG}$ ) were thus shown alternately by green and red fluorescence in adjacent sections. Direct paired immunofluorescence stained sections were regularly mounted in polyvinyl alcohol. Representative sections were remounted in polyvinyl alcohol containing para-phenylenediamine to preserve fluorescence for photographic documentation of paired staining features. ${ }^{16}$

MICROSCOPY, CELL COUNTING, AND

EVALUATION OF RESULTS

Direct paired immunofluorescence stained pre-

Table 1 Applied combination and characteristics of rhodamine and fluorescein conjugates used for quantitation of immunoglobulin-producing cells by paired immunofluorescence staining

\begin{tabular}{|c|c|c|c|}
\hline $\begin{array}{l}\text { Code and labels } \\
\text { of combined } \\
\text { conjugates }\end{array}$ & $\begin{array}{l}\text { Isotype specificity } \\
\text { of conjugates }\end{array}$ & $\begin{array}{l}\text { Optical } \\
\text { density } \\
(O D) \text { ratio* }\end{array}$ & $\begin{array}{l}\text { Working } \\
\text { conc. } \dagger \\
\text { (g IgG/litre) }\end{array}$ \\
\hline $\begin{array}{l}1 \text { 131AB } \\
\text { TRITC } \ddagger\end{array}$ & $\alpha$ chain $(\operatorname{Ig} \mathbf{A})$ & $3 \cdot 1$ & $0 \cdot 20$ \\
\hline 38B FITC\& & $\gamma$ chain $(\mathrm{IgG})$ & $2 \cdot 0$ & 0.46 \\
\hline 2 38B TRITC & $\gamma$ chain (IgG) & 4.9 & $0 \cdot 50$ \\
\hline 137B FITC & $\mu$ chain (IgM) & $2 \cdot 2$ & 1.02 \\
\hline 3 137B TRITC & $\mu$ chain (IgM) & $2 \cdot 7$ & 0.46 \\
\hline 131B FITC & $\alpha$ chain $(\operatorname{Ig} A)$ & $2 \cdot 4$ & $0 \cdot 28$ \\
\hline 4 307AB TRITC & $\delta$ chain $(\operatorname{IgD})$ & $4 \cdot 8$ & $0 \cdot 30$ \\
\hline 158B FITC & $\varepsilon$ chain (IgE) & 1.5 & $0 \cdot 17$ \\
\hline
\end{tabular}

${ }^{*} \mathrm{OD}_{280 \mathrm{~nm}} / \mathrm{OD}_{\max }$ as an estimate of degree of labelling. ${ }^{13}+$ For $20-$ $\mathrm{h}$ incubation at room temperature. ${ }^{14} \ddagger$ TRITC $=$ tetramethylrhodamine isothiocyanate. \&FITC=fluorescein isothiocyanate. parations were examined in a Leitz Orthoplan microscope equipped with a Ploem-type vertical illuminator. ${ }^{17}$ Double exposed colour slides (Ektachrome ASA 400 daylight film), were taken with an X10 oil immersion objective to show simultaneously green and red cytoplasmic fluorescence. The slides were projected at a final magnification of $\times 500$ to facilitate counting of fluorescent immunocytes with a discernible nucleus and purely green or red cell profiles with a diameter $>8 \mu \mathrm{m}$.

IgA-, IgM-, and IgG-producing immunocytes were evaluated in three serial sections with the conjugate combinations shown in Table 1. Two mucosal 'tissue units', each comprising a $500 \mu \mathrm{m}$ wide section area of the mucosa at full height (from the muscularis mucosae to the lumen), were evaluated in every section. ${ }^{6}$ Immunocytes of each of the three major isotypes were thus enumerated in two units with each conjugate. The mucosa was divided in a luminal $200 \mu \mathrm{m}$ zone and a remaining basal zone. Arithmetic means of the four counts for IgA-, IgM-, or IgG-positive cells were calculated for each specimen. The average percentage isotype distributions within each mucosal zone and for the whole tissue unit were also determined. Results for various categories of specimens were based on the sample means and standard deviations, and comparisons were done by Wilcoxon's test for unpaired samples (two-tailed) with a chosen level of significance at $5 \%$. Kendall's $\tau$ test was used for correlation analyses. ${ }^{18}$

Histopathological features were evaluated blindly in HAS-stained sections by an independent observer. Grading of chronic gastritis was based on the classification proposed by $\mathrm{Rao}^{19}$; both the antral and the body material were thereby divided into three groups $(\mathrm{A}, \mathrm{B}, \mathrm{C})$ with increasing degree of inflammation. To obtain groups of an acceptable size, this division had to be different for antral and body specimens because the inflammatory changes were much more extensive in the former. Thus, for the pyloric antrum, group A included only one specimen of grade 0 along with 24 of grade 1 , whereas groups B and C represented grades 2 and 3 , respectively. For the gastric body, group $\mathrm{C}$ included only specimens of grade 2 , whereas groups $\mathrm{A}$ and $\mathrm{B}$ represented grades 0 and 1 , respectively. In addition each specimen received a score for atrophy ( 0 to 2). Method reproducibility of cell counting and grading of inflammation have been reported previously. ${ }^{4} 20$

\section{Results}

Ig-producing immunocytes of the three main isotypes were clearly visualised in the lamina propria in 

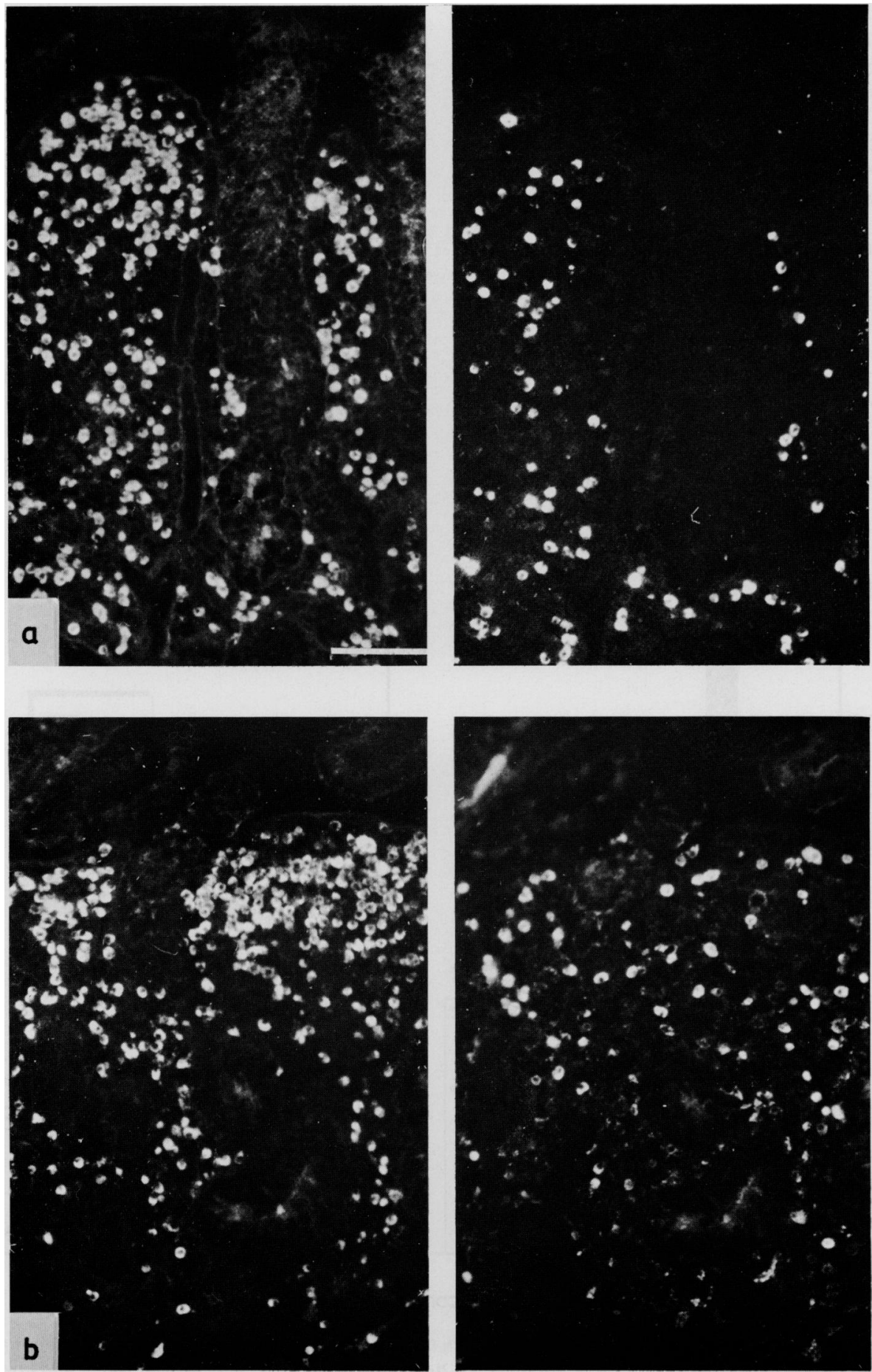

Fig. 1 Localisation of $\operatorname{IgA}$-, IgG-and IgM-producing immunocytes in gastric antral mucosa. (a) Section showing paired staining for IgA (left panel, red fluorescence) and IgG (right panel, green fluorescence). (b) Section below shows paired staining for IgA (left panel, green fluorescence) and IgM (right panel, red fluorescence). Lumen at the top. Bar=50 $\mu$ m. 
the prewashed, ethanol-fixed specimens (Fig. 1). IgD- and IgE-producing cells amounted to much less than $1 \%$ and could thus be discounted. Mast cells with peripheral IgE were often seen but were not considered in this context.

Some of the diffusely distributed extracellular IgG and $\operatorname{IgA}$ were occasionally retained due to incomplete extraction during the prefixation washing process. In double exposed colour slides of direct paired immunofluorescence-stained sections, however, such background staining appeared yellow, thereby facilitating counting of the purely green or red immunocytes.

\section{RELATION TO DEGREE OF GASTRITIS}

Quantitation of Ig-producing cells in antral mucosa Both totally and within each mucosal zone, the number of IgA and IgG immunocytes rose significantly with increasing degree of inflammation, whereas for IgM cells significant differences were found only between groups $A$ and $B$ and between groups $A$ and $C$ (Fig. 2a). From group $A$ to group $C$ the total immunocyte number per mucosal tissue unit increased from 54 to 260 for $\operatorname{IgA}$, from 8 to 25 for IgM, and from 11 to 97 for IgG (Fig. 2a). The highest relative increase was seen in the basal zone for IgG cells, which rose nine-fold from group A to $\mathrm{C}$.

\section{Isotype proportions of Ig-producing cells in antral} mucosa

IgA immunocytes showed a striking predominance. In inflammatory group A they accounted for $89 \%$ and $78 \%$ of the Ig-producing cells in the luminal and basal zone, respectively (Fig. 3a). The proportion of IgA cells did not vary significantly between groups in the luminal zone, whereas in the basal zone (and totally') significantly lower proportions of $\operatorname{IgA}$ cells

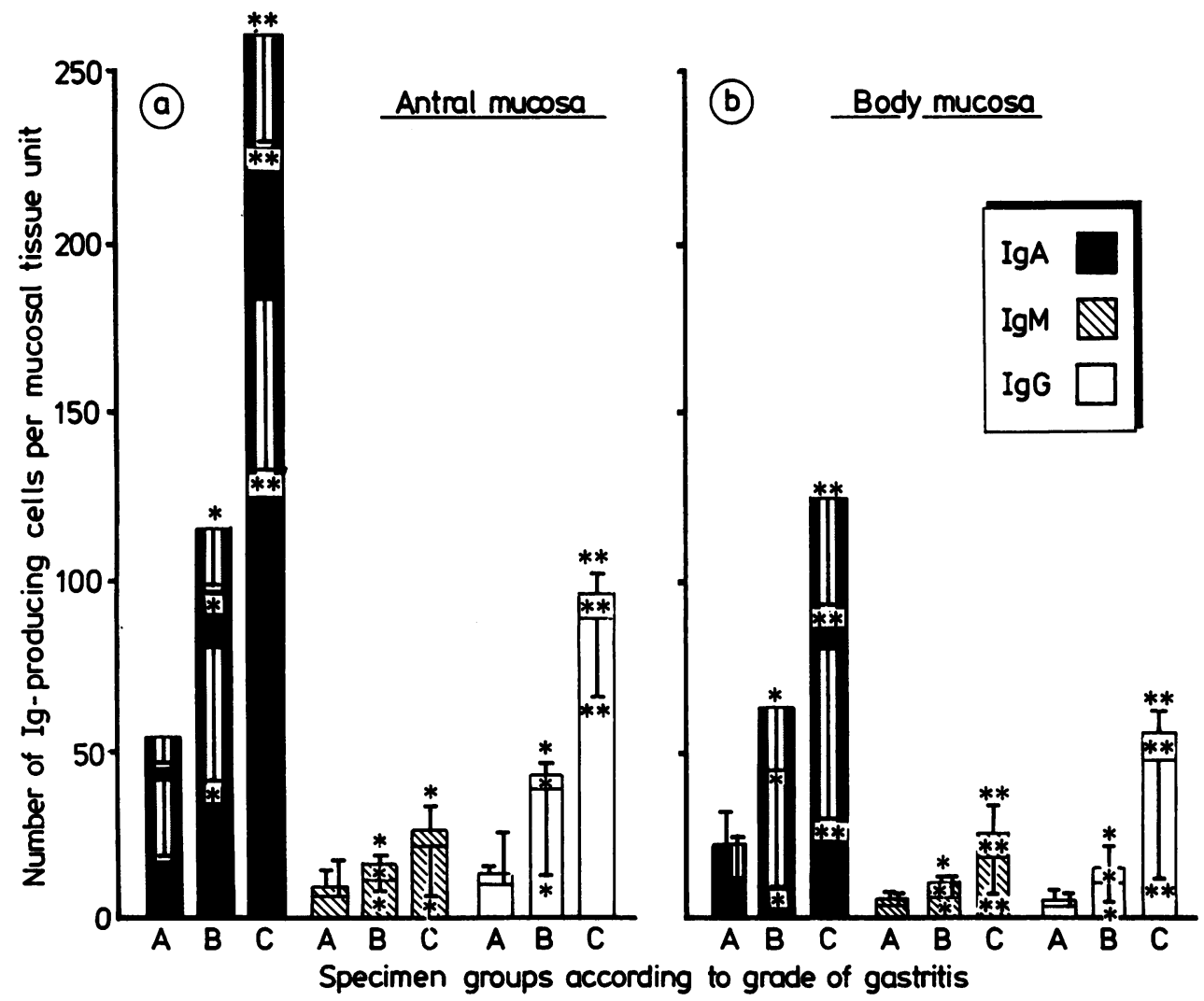

Fig. 2 Number of cells with cytoplasmic IgA, IgM, or IgG in tissue specimens of various inflammatory groups (see text) from gastric antral $(A, n=25 ; B, n=19 ; C, n=8)$ or body $(A, n=22 ; B, n=72 ; C, n=23)$ mucosa. Upper and lower parts of columns represent luminal and basal zones (see text) of mucosa, respectively. Result given as mean and standard deviation (vertical bar). Significantly increased cell counts compared with one $\left(^{*}\right)$ or both $\left(^{* *}\right)$ of the other groups are indicated (for total mucosal unit, above the column; for different zones, within the respective columns). $n=$ number of specimens. 
were found in inflammatory groups B and C $(61 \%$ and $62 \%$, respectively) compared with group $A$ $(78 \%)$. IgG cells increased significantly with increasing degree of gastritis (luminal zone, group C> A and B; basal zone and totally, groups B and C> A) (Fig. 3a). For all inflammatory groups the percentage of IgA cells was higher in the luminal zone than basally contrary to that of IgG cells (Fig. $3 a)$. The proportion of IgM immunocytes did not vary significantly between the different inflammatory groups or mucosal zones; they accounted for $5-10 \%$ of all Ig-producing cells.

Quantitation of Ig-producing cells in body mucosa The total cell count rose for all major immunocyte classes with increasing degree of inflammation (Fig. $2 b)$. The same held true when the luminal and basal zones were analysed separately (Fig. 2b). From group $\mathrm{A}$ to $\mathrm{C}$, the total number of immunocytes per mucosal unit increased from 21 to 124 for IgA, from 3 to 24 for IgM, and from 3 to 55 for IgG (Fig. 2b). As in the antral mucosa, the highest relative increase was found for IgG cells in the basal zone, where a 17 -fold rise was revealed from group $A$ to group $\mathrm{C}$.

Isotype proportions of Ig-producing cells in body mucosa

IgA immunocytes predominated in all inflammatory groups and in both mucosal zones, accounting for $57-86 \%$ of the Ig-producing cells. The proportion of IgG cells increased both luminally and basally in group $\mathrm{C}$ compared with the two other groups (Fig. $3 \mathrm{~b})$, whereas the representation of IgA cells decreased (Fig. 3b). As for the antral mucosa, the proportion of $\operatorname{IgA}$ cells was significantly higher luminally than basally in all groups whereas the reverse was true for IgG cells. No significant

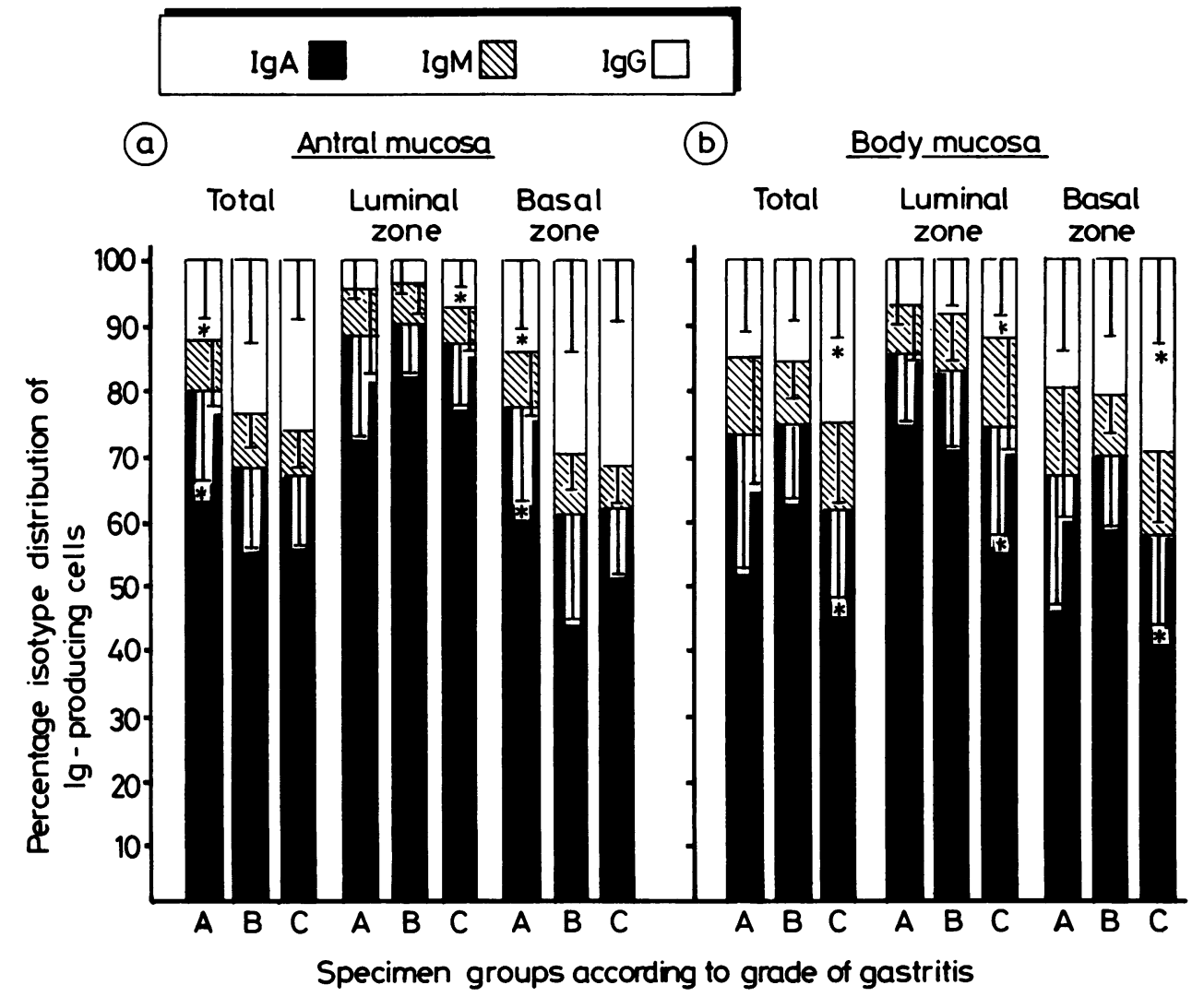

Fig. 3 Percentage isotype distribution of cells with cytoplasmic IgA, IgM, or IgG in tissue specimens of various inflammatory groups (see text and Fig. 2) from gastric antral (a) or body (b) mucosa. Result given as mean and standard deviation (vertical bar). For each isotype significant differences of one group compared with both of the others in the two mucosal zones and in the total unit are indicated $\left({ }^{*}\right)$. 
differences in the proportion of IgM immunocytes could be found between the various inflammatory groups or mucosal zones; these cells accounted for $8-14 \%$ of the total local immunocyte population.

\section{RELATION TO GLANDULAR ATROPHY}

The relation between degree of atrophy and gastritis is shown in Fig. 4. For further statistical analysis of Ig-producing cells related to glandular atrophy, antral and body specimens with $(n=33$ and $n=28$, respectively) and without ( $n=19$ and $n=89$, respectively) atrophy were first compared disregarding the degree of inflammation.

\section{Ig-producing cells in antral mucosa}

The total number of $\operatorname{IgA}$ and IgM immunocytes per mucosal unit was 122 and 15 , respectively, in specimens with atrophy compared with 85 and nine in those without; however, this apparent increase was not statistically significant. The number of IgG cells was virtually the same in both categories. The same held true with regard to isotype proportions.

\section{Ig-producing cells in body mucosa}

Compared with specimens without, those with atrophy had a raised number of $\operatorname{IgA}$ (from 55 to 103), IgM (from 7 to 19), and IgG (from 13 to 45) immunocytes per mucosal unit. These differences were statistically significant, also in each mucosal zone. When the isotype proportions were

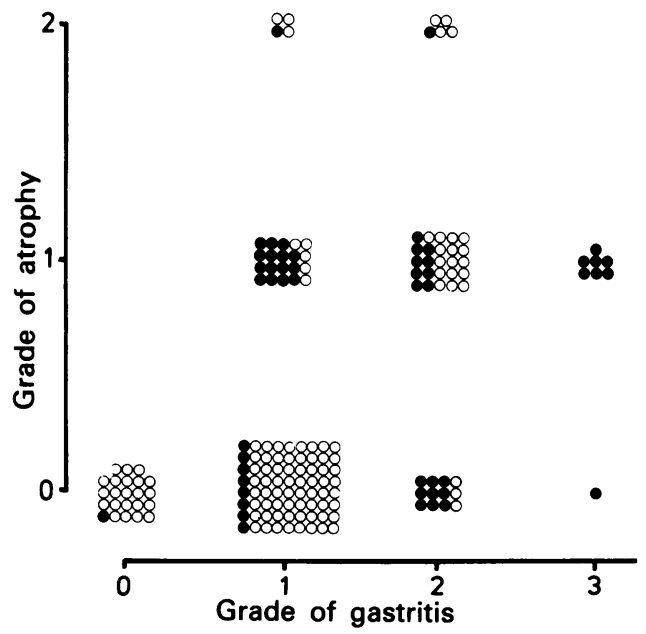

Fig. 4 Scatter diagram showing relation between grade of gastritis and atrophy in specimens from antral (O) and body (O) mucosa. Analyses (Kendall's $\tau$ test) showed significant correlation in the body specimens $(\tau=0.58, n=117$, $p<0.001)$ and in the total material $(\tau=0.48, n=169$, $p<0.001)$ but not in the antral specimens $(\tau=0.07, n=52)$. $n=$ number of specimens. considered, that for IgA cells were significantly decreased and that for IgG increased in both zones of specimens with atrophy compared with those without.

Ig-producing cells in specimens with glandular atrophy and similar degree of inflammation

As glandular atrophy and inflammatory changes were significantly correlated (Kendall's $\tau$ test) in the body mucosa (Fig. 4), specimens with the same degree of gastritis (either grade 1 or 2, Fig. 4) with or without atrophy were compared. In the body mucosa, specimens of grade 1 (group B) had a significantly higher number of $\operatorname{IgG}$ cells in the basal zone in the presence than in the absence of atrophy (Fig. 5). This held true also when the isotype proportions were considered, both in the basal zone (Fig. 5) and in the whole mucosal unit. No such differences were found in grade 2 inflammation or in the antral material.

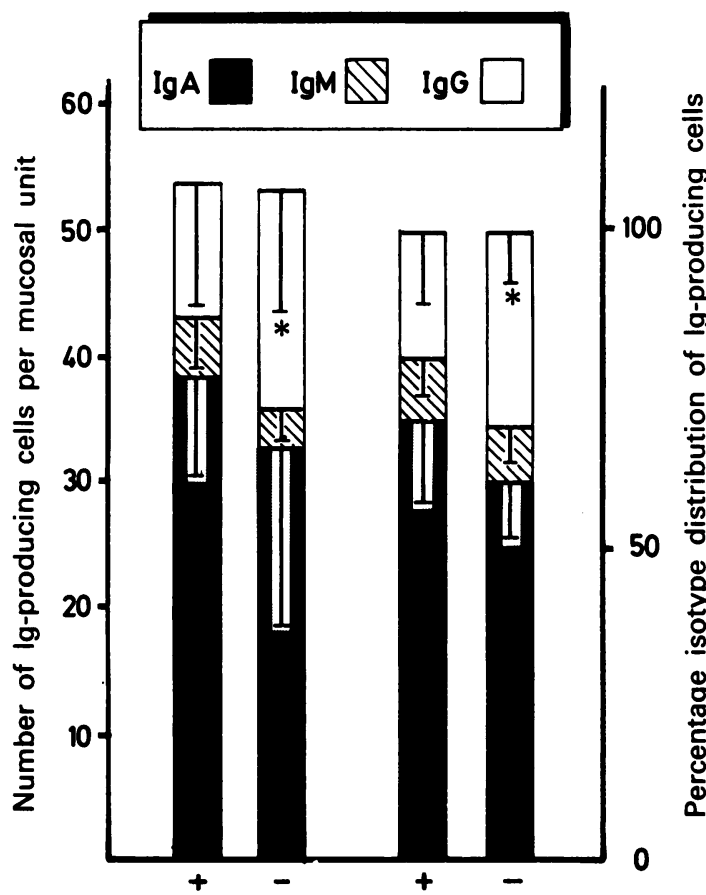

Fig. 5 Number of cells with cytoplasmic $\operatorname{IgA}, \operatorname{IgM}$, or $\operatorname{Ig} G$ per mucosal unit (left columns) and percentage isotype distribution of such cells (right columns) in basal zone of gastric body mucosa in two groups of specimens with same degree of inflammation (grade 1$)$, with $(+, n=8)$ or without $(-, n=64)$ atrophy. Result given as mean and standard deviation. Significant differences between groups are indicated $\left(^{*}\right) . n=$ number of specimens. 


\section{Discussion}

IgA-producing cells were found to be the predominant immunocyte class in both normal and inflamed human gastric mucosa as previously shown for all other secretory tissues investigated in this laboratory. ${ }^{21}$ Relatively few immunocytes were present in normal or slightly inflamed mucosa, however, whereas a striking numerical rise was demonstrated with increasing degree of gastritis. Although this rise included all three main isotypes, it was relatively largest for IgG-producing cells.

Local production of $\operatorname{IgA}$ is the crucial basis for secretory immunity in $\operatorname{man}^{3}$; and restricted parts of the gastric epithelium produce $\mathrm{SC}^{4522} 23$ and are thereby involved in receptor mediated external translocation of IgA. ${ }^{324}$ We and others have found that such epithelial transport is apparently enhanced in association with gastritis. ${ }^{45}$ The present study showed that, in addition to increased epithelial expression of $\mathrm{SC}^{45}$ a raised number of $\operatorname{IgA}$ producing cells contributes to reinforcement of secretory immunity in gastritis.

Studies of other mucosae have indicated that when insufficient antigen exclusion is afforded by the secretory immune system, a second line of defence develops involving mainly local production of IgG. ${ }^{1}$ The relatively high number of IgGproducing cells, particularly in the basal layer of inflamed gastric mucosa, may thus be of biological significance in terms of mucosal protection. As IgG antibodies are complement-activating they may not only retard influx of specific antigen but also increase epithelial penetrability for unrelated macromolecules. ${ }^{25} 26$ Such phlogistic mechanisms, resulting from an altered mucosal homeostasis, ${ }^{1}$ may contribute to perpetuation of chronic gastritis and development of glandular atrophy. In addition to activating complement, IgG antibodies can arm $\mathrm{K}$ cells which may exert cytotoxicity of target cells. Although little as yet is known about the antibody specificities of gastric immune responses, local IgG cells with a cytoplasmic product binding intrinsic factor have been found in pernicious anaemia. ${ }^{27}$ Such antibodies may conceivably cause damage of gastric glands. In simple chronic gastritis, serum autoantibodies to gastrin-producing $(\mathrm{G})$ cells have been reported ${ }^{28}$ and these may well be of local origin.

When body specimens with the same grade of gastritis were compared in relation to the presence or absence of atrophy (Fig. 5), the total number of Ig-producing cells per mucosal unit was the same in both groups. In specimens with gastritis of grade 1 (group B), however, IgG cells were relatively more increased in the basal zone of the body mucosa in association with atrophy. The lack of such a relation in gastritis of grade 2 might be explained by the higher overall density of IgG cells in this group; the same was true in the antral mucosa where inflammatory grades 1 and 2 signified more severe gastritis than the comparable grades assigned for the body mucosa.

Several difficulties exist in comparing our results with those from previous immunohistochemical studies of Ig-producing cells in human gastric mucosa (Table 2). The gastric region under investigation has not always been specified ${ }^{29} 38$ and histopathological classification of the specimens has often been lacking ${ }^{33}$ or based on different criteria. ${ }^{23}{ }^{32}$ In some papers, quantitative data have not been reported ${ }^{38}{ }^{39}$ or they have been based on estimation of cell densities ${ }^{23}{ }^{29-35}$ rather than on the total number of immunocytes in a mucosal tissue unit as determined in the present study. Generally, when normal and inflamed gastric mucosae have been compared, most studies have shown an absolute increase in the numbers of cells producing one or more of the three main Ig isotypes. ${ }^{29-31} 343738$ Nevertheless, a clear-cut and significant numerical immunocyte increase according to the histopathological grade of gastritis has not been shown in previous studies.

When the immunocyte isotype proportions are considered, four previous studies give data for normal antral mucosa ${ }^{31}{ }^{35-37}$ that show a percentage of IgA (range, $63-88 \%$ ), IgM (range, 4-23\%), and IgG (range, 6-21\%) cells comparable with our findings in normal and slightly inflamed antral mucosa (Table 2). The same is true in three studies reporting data for normal body mucosa, ${ }^{31} 3536$ in which the median values for $\operatorname{IgA}(76 \%), \operatorname{IgM}(9 \%)$, and IgG $(13 \%)$ cells fit well with ours (Table 2$)$.

Three previous ${ }^{313637}$ studies on antral gastritis may be compared with ours - that of Slaouii ${ }^{36}$ reporting very similar data. Conversely, the IgG figure is smaller in the study of Spreeuwel, ${ }^{37}$ and the IgM percentage reported by Camilleri ${ }^{31}$ is relatively high. Our result for inflamed body mucosa is also most like that of Slaouii ${ }^{36}$ whereas Camilleri ${ }^{31}$ again reports strikingly high IgM figures (33\%).

The normal antral IgA- to IgG-cell ratio ranged in four previous studies from 4 to $14 .^{31}{ }^{35-37}$ In three, a decrease in this ratio was found in connection with gastritis. ${ }^{31} 3637$ In our study the same ratio decreased from 5 to 3 with increasing grade of antral gastritis.

For normal body mucosa we calculated an IgAto IgG-cell ratio of 6 which was similar to that reported in three previous studies. ${ }^{31} 3536$ A decrease of this ratio with increasing degree of gastritis was shown by us and others with two 
exceptions. ${ }^{29}{ }^{34}$ Such a decrease was reported to be particularly marked in atrophic gastritis associated with pernicious anaemia. ${ }^{30}{ }^{31}$ Odgers and Wangel ${ }^{30}$ described two such patient groups, one with a normal gastric IgA- to IgG-cell ratio and another with a ratio of less than 1 . They proposed that in some patients with pernicious anaemia, a strikingly reduced proportion of $\operatorname{IgA}$ immunocytes could represent a primary defect predisposing to mucosal damage. They showed in fact that the reduced ratio could be ascribed to a decrease of the IgA- and an increase of IgG-cell density in the lamina propria. It should be noted, however, that a decreased cell density might be caused by oedema; a better reflection of the local immunological activity is obtained by cell enumeration based on a mucosal tissue unit as carried out in the present study. Nevertheless, regardless of the quantitative method used, a reduced IgA- to IgG-isotype ratio reflects an altered immunological homeostasis in the mucosa. ${ }^{1}$

The biological significance of locally produced gastric IgM is difficult to evaluate. Because IgM can be transported by SC-producing epithelium, it may contribute to external defence although being less stable than secretory IgA. ${ }^{3}$ The number of IgMproducing cells varies considerably among different secretory tissues, the highest proportion being found in the proximal small intestine. ${ }^{40}$ It is unknown whether such variations in local isotype profiles may be ascribed to dissimilar precursor pools of B cells

Table 2 Immunohistochemical studies of Ig-producing cells in human gastric mucosa

\begin{tabular}{|c|c|c|c|c|c|c|c|c|c|}
\hline \multirow[b]{2}{*}{ Gastric region } & \multirow{2}{*}{$\begin{array}{l}\text { Histological } \\
\text { classification }\end{array}$} & \multicolumn{3}{|c|}{ Cell quantitation } & \multicolumn{3}{|c|}{ Percentage distribution } & \multirow{2}{*}{$\begin{array}{l}\lg A / \lg G \\
\text { ratio }\end{array}$} & \multirow[b]{2}{*}{ Reference } \\
\hline & & $\lg A$ & $\lg M$ & $\lg G$ & $\operatorname{Ig} A$ & $\lg M$ & $\operatorname{Ig} G$ & & \\
\hline \multirow[t]{2}{*}{ Not specified } & Normal & $222,000^{*}$ & 25,000 & 16,000 & 84 & 10 & 6 & $13 \cdot 9 / 1$ & (29) \\
\hline & Atrophic gastritis $\dagger$ & 354,000 & 46,000 & 15,000 & 85 & 11 & 4 & $23 \cdot 6 / 1$ & \\
\hline \multirow[t]{3}{*}{ Body mucosa } & Normal & $285 \ddagger$ & $52 \cdot 8$ & $35 \cdot 6$ & 76 & 14 & 10 & $8 / 1$ & (30) \\
\hline & Atrophic gastritis $\dagger$ & $308 \cdot 8$ & $59 \cdot 8$ & $38 \cdot 6$ & 76 & 15 & 9 & $8 / 1$ & \\
\hline & Atrophic gastritis $\dagger$ & $37 \cdot 5$ & $34 \cdot 7$ & $61 \cdot 4$ & 28 & 26 & 46 & $0 \cdot 6 / 1$ & \\
\hline \multirow[t]{2}{*}{ Antral mucosa } & Normal & $70 \ddagger$ & 25 & 15 & 63 & 23 & 14 & $4 \cdot 6 / 1$ & $(31)$ \\
\hline & Superficial gastritis & $83 \cdot 8$ & $58 \cdot 8$ & $22 \cdot 1$ & 51 & 36 & 13 & $3 \cdot 8 / 1$ & \\
\hline \multirow[t]{4}{*}{ Body mucosa } & Normal & 45 & $17 \cdot 5$ & $9 \cdot 5$ & 63 & 24 & 13 & $4 \cdot 7 / 1$ & \\
\hline & Superficial gastritis & $82 \cdot 5$ & $53 \cdot 8$ & $23 \cdot 4$ & 52 & 33 & 15 & $3 \cdot 5 / 1$ & \\
\hline & Atrophic gastritis $\dagger$ & $121 \cdot 3$ & 65 & $54 \cdot 4$ & 50 & 27 & 23 & $2 \cdot 2 / 1$ & \\
\hline & Atrophic gastritis & $57 \cdot 5$ & $32 \cdot 5$ & $16 \cdot 7$ & 54 & 30 & 16 & $3 \cdot 4 / 1$ & \\
\hline Antral mucosa & different diagnosis & & & & $76 \S$ & 13 & 11 & $6 \cdot 9 / 1$ & $(32)$ \\
\hline Body mucosa & $\begin{array}{l}\text { No histological } \\
\text { classification } \\
\text { various diagnoses }\end{array}$ & & & & $78 \S \|$ & 13 & 6 & $13 / 1$ & (33) \\
\hline Antral mucosa & Normal and mild gastritis & $39,670^{*}$ & 12,099 & 8,655 & 66 & 20 & 14 & $4 \cdot 6 / 1$ & $(34)$ \\
\hline Body mucosa & Moderate gastritis & 135,959 & 20,419 & 9,681 & 82 & 12 & 6 & $14 / 1$ & \\
\hline Antral mucosa & Normal & & & & $75 \S 9$ & 4 & 21 & $3 \cdot 6 / 1$ & (35) \\
\hline Body mucosa & Normal & & & & 80 & 4 & 16 & $5 / 1$ & \\
\hline \multirow[t]{2}{*}{ Antral mucosa } & $\begin{array}{l}\text { Specimens } \\
\text { without } \mathrm{IM}^{* *}\end{array}$ & $700 \ddagger \rrbracket$ & 60 & 115 & 809 & 7 & 13 & $6 \cdot 1 / 1$ & (23) \\
\hline & with $\mathrm{IM}^{* *}$ & 440 & 25 & 50 & 85 & 5 & 10 & $8 \cdot 8 / 1$ & \\
\hline Body mucosa & Not specified & 480 & 50 & 90 & 77 & 8 & 15 & $5 \cdot 3 / 1$ & \\
\hline \multirow[t]{3}{*}{ Antral mucosa } & Normal & & & & $75 † \dagger \ddagger$ & 8 & 15 & $5 / 1$ & (36) \\
\hline & Gastritis & & & & 67 & 7 & 22 & $3 / 1$ & \\
\hline & Gall reflux gastritis & & & & $51|\||$ & 16 & 18 & $2 \cdot 8 / 1$ & \\
\hline \multirow[t]{3}{*}{ Body mucosa } & Normal & & & & 76 & 9 & 12 & $6 \cdot 3 / 1$ & \\
\hline & Gastritis & & & & 69 & 6 & 20 & $3 \cdot 5 / 1$ & \\
\hline & Gall reflux gastritis & & & & 63ๆף & 13 & 15 & $4 \cdot 2 / 1$ & \\
\hline \multirow[t]{2}{*}{ Antral mucosa } & Normal & $14+\dagger$ & 1 & 1 & 88 & 6 & 6 & $14 / 1$ & (37) \\
\hline & gastritis & 186 & 18 & 33 & 78 & 8 & 14 & $5 \cdot 6 / 1$ & \\
\hline \multirow[t]{3}{*}{ Antral mucosa } & $\begin{array}{l}\text { Normal and low- } \\
\text { grade gastritis }\end{array}$ & $54 \cdot 1 \dagger \dagger$ & $7 \cdot 8$ & $11 \cdot 0$ & 80 & 8 & 12 & $4 \cdot 9 / 1$ & $\begin{array}{r}\text { Present } \\
\text { study }\end{array}$ \\
\hline & Moderate gastritis & $115 \cdot 8$ & $15 \cdot 3$ & $42 \cdot 5$ & 68 & 9 & 23 & $2 \cdot 7 / 1$ & \\
\hline & Severe gastritis & $260 \cdot 1$ & $25 \cdot 0$ & $96 \cdot 7$ & 67 & 7 & 26 & $2 \cdot 7 / 1$ & \\
\hline \multirow[t]{3}{*}{ Body mucosa } & Normal & $20 \cdot 8$ & $2 \cdot 6$ & $3 \cdot 5$ & 73 & 13 & 14 & $5 \cdot 9 / 1$ & \\
\hline & Low-grade gastritis & $62 \cdot 2$ & $7 \cdot 8$ & $14 \cdot 4$ & 74 & 9 & 17 & $4 \cdot 3 / 1$ & \\
\hline & Moderate gastritis & $124 \cdot 1$ & $24 \cdot 2$ & $55 \cdot 2$ & 62 & 13 & 25 & $2 \cdot 2 / 1$ & \\
\hline
\end{tabular}

*Number of cells per $\mathrm{mm}^{3}$ of interstitial area. $†$ Patients with pernicious anaemia. $\ddagger$ Number of cells per $\mathrm{mm}^{2}$ of lamina propria. $\S$ Number of cells per area of lamina propria. \|IgE cells $=3 \%$. \Approximately calculated. ${ }^{* *}$ Intestinal metaplasia. $\dagger+$ Number of cells per mucosal unit, defined as a $500 \mu \mathrm{m}$ wide area at full height of the mucosa. $\ddagger \ddagger$ Exclusively IgD and IgE cells. $|\|| \operatorname{IgE}=12 \%$. $\| \uparrow \operatorname{IgE}=7 \cdot 5 \%$. 
homing to the different sites or reflect region-related topical antigenic or mitogenic effects on local B-cell differentiation. We found a relatively high proportion of IgM cells in the gastric mucosa, although it was much lower than that reported by Camilleri et $a l^{31}$ As IgM has complement-activating properties, its enhanced local production in gastritis may well be of immunopathological importance.

A striking preponderance of $\operatorname{IgA}$ immunocytes was found in gastric mucosa, signifying an active secretory immune system. With increasing grade of gastritis, the total number of immunocytes was significantly increased but disproportionately so for the IgG isotype. Enhanced local production of IgG probably reflects a second line of defence which over time, however, through immunopathological mechanisms may contribute to glandular atrophy and perpetuation of gastritis. The subclasses of IgG included in the gastric immune responses are unknown and will be mapped in further immunohistochemical studies by means of monoclonal antibodies.

This work was supported by the Norwegian Cancer Society and by Anders Jahre's Fund.

\section{References}

1 Brandtzaeg P. The humoral immune systems of human gastrointestinal tract. Monogr Allergy 1981; 17: 195-221.

2 Hanson LA, Brandtzaeg P. The mucosal defense system. In: Stiehm ER, Fulginiti VA, eds. Immunological disorders in infants and children. London: Saunders 1980: 137-64.

3 Brandtzaeg P. Role of J chain and secretory component in receptor-mediated glandular and hepatic transport of immunoglobulins in man. Scand J Immunol 1985; 22: 111-46.

4 Valnes K, Brandtzaeg P, Elgjo K, Stave R. Specific and nonspecific humoral defense factors in the epithelium of normal and inflamed gastric mucosa. Gastroenterology 1984; 86: 402-12.

5 Isaacson P. Immunoperoxidase study of the secretory immunoglobulin system and lysozyme in normal and diseased gastric mucosa. Gut 1982; 23: 578-88.

6 Brandtzaeg P, Baklien K, Fausa O, Hoel PS. Immunohistochemical characterization of local immunoglobulins formation in ulcerative colitis. Gastroenterology 1974; 66: 1123-36.

7 Baklien K, Brandtzaeg P. Immunohistochemical characterization of local immunoglobulin formation in Crohn's disease of the ileum. Scand J Gastroenterol 1976 11: 447-57.

8 Rognum TO, Brandtzaeg P, Baklien K, Hognestad J. Immunoglobulin-producing cells in the "transitional" mucosa adjacent to adenocarcinomas of the human large bowel. Int J Cancer 1979; 23: 165-73.

9 Rosekrans PCM, Meijer CJLM, van der Wal AM,
Cornelisse $\mathrm{CJ}$, Lindeman $\mathrm{J}$. Immunoglobulincontaining cells in inflammatory bowel disease of the colon. A morphometric and immunohistochemical study. Gut 1980; 21: 941-7.

10 Scott H, Ek J, Baklien K, Brandtzaeg P. Immunoglobulin-producing cells in jejunal mucosa of children with coeliac disease on a gluten-free diet and after gluten challenge. Scand J Gastroenterol 1980; 15: 81-8.

11 Brandtzaeg P. Mucosal and glandular distribution of immunoglobulin compounds. Immunohistochemistry with a cold ethanol-fixation technique. Immunology 1974; 26: 1101-14.

12 Brandtzaeg $P$. Conjugates of immunoglobulin $G$ with different fluorochromes. I. Characterization by anionic-exchanges chromatography. Scand J Immunol 1973; 2: 273-90.

13 Brandtzaeg P. Conjugates of immunoglobulin $G$ with different fluorochromes. II. Specific and non-specific binding properties. Scand J Immunol 1973; 2: 333-48.

14 Brandtzaeg P. Prolonged incubation time in immunohistochemistry: effects on fluorescence staining of immunoglobulins and epithelial components in ethanol- and formaldehyde-fixed paraffin-embedded tissues. J Histochem Cytochem 1981; 29: 1302-15.

15 Stave R, Brandtzaeg P. Fluorescence staining of gastric mucosa. A study with special reference to parietal cells. Scand J Gastroenterol 1977; 12: 885-91.

16 Valnes K, Brandtzaeg P. Retardation of immunofluorescence fading during microscopy. $J$ Histochem Cytochem 1985; 33: 755-61.

17 Ploem JS. The use of vertical illuminator with interchangeable dichroic mirrors for fluorescence microscopy with incident light. $Z$ Wiss Mikr 1967; 68: 129-42.

18 Kendall M. Rank correlation methods. London: Charles Griffin, 1974.

19 Rao SS, Krasner N, Thomsen TJ. Chronic gastritis - a simple classification. J Pathol 1975; 117: 93-6.

20 Valnes K, Brandtzaeg P, Hanssen LE, Stave R, Larsen $\mathrm{S}$, Londong W. Quantitation of immunoglobulin- and peptide hormone-producing cells in gastrointestinal mucosa. Comparison of direct immunofluorescence and the unlabelled antibody peroxidase-antiperoxidase method. Histochem J 1983; 15: 1011-20.

21 Brandtzaeg P. The secretory immune system of lactating human mammary glands compared with other exocrine organs. Ann NY Acad Sci 1983; 409: 353-82.

22 Maeda S. Studies of immunoglobulins in gastric juice and gastric mucosa. IV. Studies on secretory component in gastric mucosa. Sapporo Med J 1977; 46: 409-20.

23 Ohta Y, Kino I, Kato Y, Aoyama Y. The distribution and localization of immunoglobulin in the gastric mucosa and gastric cancer. Acta Pathol Jpn 1979; 29: 523-31.

24 Brandtzaeg P, Prydz $H$. Direct evidence for an integrated function of $\mathrm{J}$ chain and secretory component in epithelial transport of immunoglobulins. Nature 1984; 311: 71-73.

25 Brandtzaeg P, Tolo K. Mucosal penetrability enhanced by serum-derived antibodies. Nature 1977; 266: 262-3.

26 Lim PL, Rowley D. The effect of antibody on the intestinal absorption of macromolecules and on 
intestinal permeability in adult mice. Int Arch Allergy Appl Immunol 1982; 68: 41-6.

27 Baur S, Koo N, Taylor KB. The immunoglobulin class of autoantibody-containing cells in the gastric mucosa. Immunology 1970; 19: 891-4.

28 Vandelli C, Bottazzo GF, Doniach D, Franceschi F. Autoantibodies to gastrin-producing cells in antral (type B) chronic gastritis. N Engl J Med 1979; 300: 1406-10.

29 Crabbé PA, Heremans JF. The distribution of immunoglobulin-containing cells along the human gastrointestinal tract. Gastroenterology 1966; 51: 305-16.

30 Odgers RJ, Wangel AG. Abnormalities in IgAcontaining mononuclear cells in the gastric lesions of pernicious anaemia. Lancet 1968; 2: 846-9.

31 Camilleri JP, Bérault J, Picker M, Dièbold J. Distribution des cellules immunosécrétrices dans la muqueuse gastrique humaine, a l'état normal et au cours des gastrites chroniques. A propos de 46 gastro-biopsies dirigées. Biol Gastroenterol 1973; 6: 231-41.

32 Chen ST, Tobe T. Cellular sites of immunoglobulins. IV. Studies of antral mucosa of human stomachs. Digeston 1974; 10: 177-83.

33 Brown WR, Borthistle BK. Chen St. Immunoglobulin $\mathrm{E}$ (IgE) and IgE-containing cells in human gastrointestinal fluids and tissues. Clin Exp Immunol 1975; 20: $227-37$.
34 Maeda S. Studies of immunoglobulins in gastric juice and gastric mucosa. II. Studies of secretory $\operatorname{IgA}$ and the free secretory component and other immunoglobulins in gastric juice, and distribution of immunoglobulin containing cells in the gastric mucosa. Sapporo Med J 1977; 46: 395-403.

35 Kreuning J, Bosman FT, Knuiper G, v.d. Wal AM, Lindeman J. Gastric and duodenal mucosa in healthy subjects. J Clin Pathol 1978; 31: 69-77.

36 Slaoui H, André C, Dechavanne M, Tolot F. Immunofluorescence studies of mucosal B lymphocytes in bile reflux gastritis. Digestion 1979; 19: 131-3.

37 Van Spreeuwel JP, Lindeman J, van der Wal AM, Weterman I, Kreuning J, Meijer CJLM. Morphological and immunohistochemical findings in upper gastrointestinal biopsies of patients with Crohn's disease of the ileum and colon. J Clin Pathol 1982; 35: 934-40.

38 Brus J, Siegel H, Yamaguchi N, Glass GBJ. Immunoglobulins $\operatorname{IgA}$ and $\operatorname{IgG}$ in gastric mucosa of patients with atrophic gastritis and pernicious anemia. Scand $J$ Gastroenterol 1968; 3: 43-57.

39 Chapel HM, Hoare AM. A study of the aetiology of gastritis following gastric surgery. I. Immunofluorescent studies of the gastric mucosa. Clin Exp Immunol 1979; 37: 441-4.

40 Brandtzaeg P, Valnes K. Scott H, Rognum TO, Bjerke $\mathrm{K}$, Baklien $\mathrm{K}$. The human gastrointestinal secretory immune system in health and disease. Scand J Gastroenterol. 1985; 20 (suppl 114): 17-38. 